\title{
Action of the Extracts of Pluchea sagittalis on the Absorptive Characteristics of the Gastrointestinal Tract.
}

\author{
Marilise E. Burger* , Bernardo Baldisserotto, Elisângela P. Teixeira and Joceana Soares. \\ Department of Physiology, Federal University of Santa Maria, 97.119-900, Santa Maria - RS, Brasil
}

\begin{abstract}
Pluchea sagittalis (Lam.) Cabrera, (quitoco or erva lucera) is commonly used to treat digestive disorders in Southern Brazil and countries of the South Cone. The crude aqueous extracts from the leaves, stalks or flowers were used in acute oral toxicity in mice and in pharmacological studies to determine the gastrointestinal transport of water, sodium, and potassium in rats. The oral administration of $5000 \mathrm{mg} / \mathrm{kg}$ of extracts examined did not produce signs of intoxication nor induce the death of any mice during the period of 14 days. The extracts from the leaves and stalk have reduced the absorption of water in the jejunum and jejunum and ileum, respectively with relation to the control. There was an absorption of sodium with the administration of these extracts, especially those from the flowers, when compared with that of the control. There was an increase in the absorption of potassium in different parts of the gastrointestinal tract in comparison to that of the control, being increased in most parts with the application of extracts from the stalks. It could be concluded that the extracts from the stalk, leaves and flowers of $P$. sagittalis have substances that alter the absorptive characteristics of several portions of the gastrointestinal mucosa.
\end{abstract}

Key-words : Pluchea, ion transport, gastrointestinal tract absorption, acute toxicity.

\section{INTRODUCTION}

Pluchea sagittalis (Lam.) Cabr. (Asteraceae) (quitoco or erva lucera) grows in the moist regions of North-west of Argentina, Uruguay, Southern Brazil, and Paraguay. This plant is commonly used for its medicinal properties (stomachic and digestive), and its extract is part of a digestive and appetizer liqueur. According to the same author, Pluchea sagittalis is an herbaceous and perennial plant, with vigorous and ramified roots. The aerial stalks are 1.5 to $1.8 \mathrm{~m}$ high, and the diameter is approximately $20 \mathrm{~mm}$ (1). Chemical compounds such as fatty acids, glycosides, steroids, quaternary base pluchine, flavonoids and triterpenes were identified and isolated from another species of the same genus, Pluchea lanceolata C. B. Clarke. Some of these triterpenes have antiinflammatory activity $(2,3,4)$. Terpenoids, lignan glycosides, eudesmane-type sesquiterpenes, and terpenic glycosides were identified in Pluchea indica (L.) $(3,4)$. The same species have antiinflammatory effect on the exudative, proliferative, and chronic stages (5), and a protective action on the gastric mucosa (6). A study of 11 species of Asteraceae from Argentina revealed that $P$. sagittalis has one of the highest contents of caffeoylquinic acids (7). Other compounds isolated from this plant are: essential oils, sesquiterpenes (8), isochlorogenic acid and 3,4- ;4,5- e 3,5dicaffeoylquinic acids (9). The essential oils of $P$. sagittalis are $\mathrm{d}-\alpha$-pinene, $\mathrm{d}$-canphene, cineol, p-cimene, linalolol, l-canphor, alfa-terpineol, borneol, caryophyllene, humulene, and three unknown substances (8). Methylated flavonoids were isolated from the chloroform extract of this species; isochlorogenic acid from the ethereal extract, and chlorogenic and caffeic acid from the ethyl acetate extract (7). This plant has also presented coleretic and colagogue actions when administered in individuals with digestive diseases (10).

*Author for correspondence 
The purpose of this study is to investigate the action of the crude aqueous extracts of $P$. sagittalis on the transport of water, $\mathrm{Na}^{+}$, and $\mathrm{K}^{+}$ on the gastrointestinal tract. In addition, the determination of the acute toxicity of the crude aqueous extracts was also investigated.

\section{MATERIAL AND METODS}

Collect of plants - Pluchea sagittalis (Lam.) Cabr. (Asteraceae) was collected during the flowering phases (March and April, 1994), in Santa Maria, Southern Brazil. A voucher specimen was prepared and registered in the herbarium of the Department of Biology of the Federal University of Santa Maria (SMDB $n^{\circ}$ 4022).

Preparation of extracts - Aerial portions were separated in leaves, stalk, and flowers and maintained in the oven with ventilation $\left(50^{\circ} \mathrm{C}\right)$ for drying and stabilization of the plant. Later the material was pulverized in a Tigre A-3 mill and stored in brown glass previously deranged and labeled. To prepare the extracts $50 \mathrm{~g}$ of leaves, stalk or flowers were boiled in $500 \mathrm{ml}$ of water for $10 \mathrm{~min}$. This process was repeated three times to obtain adequate drainage of the plant, and the aqueous extract was concentrated in a Büchi rotary evaporator. The concentrate was dried in a water-bath $\left(60^{\circ} \mathrm{C}\right)$, and afterwards remained in oven for $4 \mathrm{~h}$ at the same temperature, until the weight remained constant. The dry residue was scraped and stored in a brown glass under refrigeration. The concentration of $\mathrm{Na}^{+}$and $\mathrm{K}^{+}$in the crude extract of $P$. sagittalis was determined by flame spectrophotometry.

Experimental - Adult mice, of both sexes (28,3 $\pm 0,55 \mathrm{~g}$ ), in $2 \mathrm{~h}$ fasting, that received by gavage one dose of extract $(625 ; 1250 ; 2500$, or 5000 $\mathrm{mg} / \mathrm{kg}$ live weight) were used to determine the acute oral toxicity of the extracts of leaves, stalk, and flowers of $P$. sagittalis. After the administration the mice were given food and water "ad libitum" at a temperature of $25^{\circ} \mathrm{C}$. Behavior, mortality rate, and general state of the animals were observed during 14 days (11).
Adult Wistar rats (150 - $200 \mathrm{~g})$ of both sexes, in fasting $(24 \mathrm{~h})$, were used to investigate the transport of water, $\mathrm{Na}^{+}$, and $\mathrm{K}^{+}$, and were sacrificed by cervical dislocation. The abdomen was opened, and the gastrointestinal tract isolated in the following portions: stomach, duodenum, jejunum, ileum and colon. These portions were everted and washed with Tyrode solution (in $\mathrm{mM}$ : $137.0 \mathrm{NaCl} ; 2.7 \mathrm{KCl} ; 1.8$ $\mathrm{CaCl}_{2} ; 1.0 \quad \mathrm{MgCl}_{2} .6 \mathrm{H}_{2} \mathrm{O} ; 11.9 \mathrm{NaHCO}_{3} ; 0.4$ $\left.\mathrm{NaH}_{2} \mathrm{PO}_{4} \cdot \mathrm{H}_{2} \mathrm{O} ; 5.5 \quad \mathrm{C}_{6} \mathrm{H}_{12} \mathrm{O}_{6}\right)$. The flow of water, $\mathrm{Na}^{+}$, and $\mathrm{K}^{+}$was determined as described by Baldisserotto et al. (12). To verify the "in vitro" effect of $P$. sagittalis, the extracts were placed in the infusion, in contact with the intestinal mucosa $(500 \mathrm{mg} / \mathrm{l})$. The flow of water, $\mathrm{Na}^{+}$, and $\mathrm{K}^{+}$was expressed as $\mu$ of water or $\mu \mathrm{Eg}$ of ion transferred from mucosa to serosa (negative values) or serosa to mucosa (positive values) in function of the weight of the tissue (stomach, duodenum, jejunum, ileum or colon) in g during $1 \mathrm{~h}(\mu \mathrm{l}$ or $\mu \mathrm{Eg} / \mathrm{g}$ tissue.h).

In order to verify the significance of the flow of water, $\mathrm{Na}^{+}$, and $\mathrm{K}^{+}$, and the difference between these flows in the presence or absence of the extracts, the t-Student test was used. The minimum significant level was $p<0.05$. All test were made with the aid of Microstat program (Ecosoft, Inc.). Figures were elaborated with the Slide Write Plus program (Advance Graphics Software, Inc.). All values were expressed as the mean $\pm \mathrm{SE}$.

\section{RESULTS}

The extract of $P$. sagittalis of $1000 \mathrm{mg} / \mathrm{l}$ had $204 \mathrm{mg} / \mathrm{l} \mathrm{Na}^{+}$and $98.8 \mathrm{mg} / \mathrm{l} \mathrm{K}^{+}$. These values were similar for extracts of leaves, stalks, and flowers.

The extracts from the leaves, stalk, and flowers (in the tested doses) did not induce deaths of mice or signs of intoxication during the experiments of acute oral toxicity. All studied portions of the gastrointestinal tract absorbed water in the control group. The extract from the leaves reduced the absorption of water in the 
jejunum, and the extract from the stalk reduced this absorption in the jejunum and ileum. The

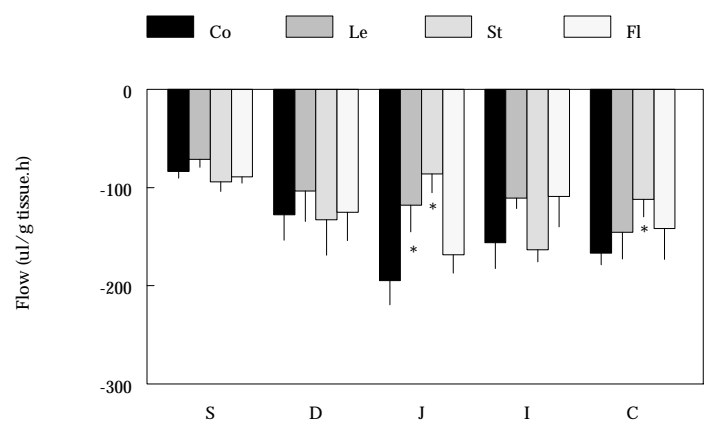

Figure 1. Action of the crude aqueous extracts of the leaves (Le), stalk (St) and flowers $(\mathrm{Fl})$ of Pluchea sagittalis $(500 \mathrm{mg} / \mathrm{l})$ on the flow of water in the stomach (S), duodenum (D), jejunum (J), ileum (I), and colon $(\mathrm{C})$, in relation to the control group $(\mathrm{Co})$. Data as mean \pm S.E.M.

Number of experiments: 8 .

Statistically different from control $* \mathrm{p}<0.05$

All studied portions of the gastrointestinal tract of the control group did not present flow of $\mathrm{Na}^{+}$, but all studied portions absorbed $\mathrm{K}^{+}$. The extract from the leaves increased the absorption of $\mathrm{Na}^{+}$in the jejunum, ileum and colon, and the absorption of $\mathrm{K}^{+}$in the ileum and colon. The extract from the stalk increased the absorption of both $\mathrm{Na}^{+}$and $\mathrm{K}^{+}$in the duodenum, jejunum, ileum, and colon. The extract from the flowers increased the absorption of $\mathrm{Na}^{+}$in all studied portions, and that of $\mathrm{K}^{+}$in the stomach and jejunum (figure 2, 3).

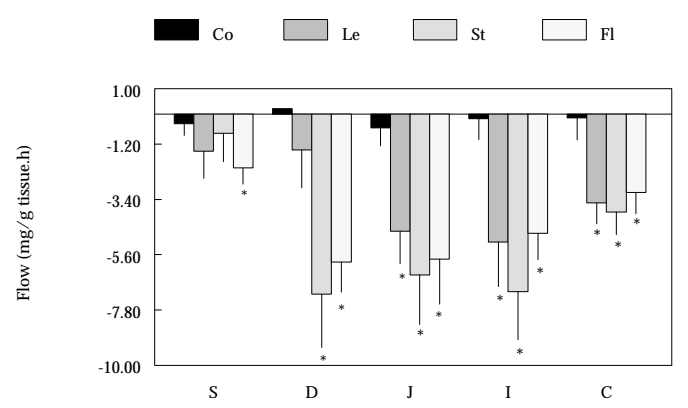

Figure 2. Action of the crude aqueous extracts of leaves (Le), stalk (St) and flowers (Fl) of Pluchea sagittalis $(500 \mathrm{mg} / \mathrm{l})$ on the flow of $\mathrm{Na}^{+}$in the stomach (S), duodenum (D), jejunum (J), ileum (I), and colon $(\mathrm{C})$, in relation to the control group $(\mathrm{Co})$. Data as mean \pm S.E.M.

Number of experiments: 8 . extract from the leaves did not alter the flow of water (figure 1).

Statistically different from control $* \mathrm{p}<0.05$

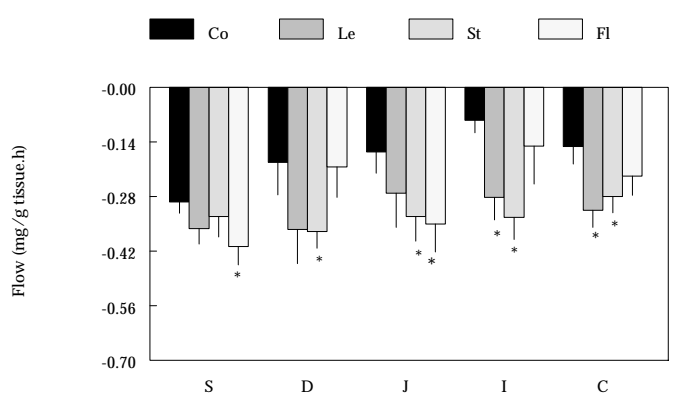

Figure 3. Action of the crude aqueous extracts of leaves (Le), stalk (St) and flowers (Fl) of Pluchea sagittalis $(500 \mathrm{mg} / \mathrm{l})$ on the flow of $\mathrm{K}^{+}$in the stomach (S), duodenum (D), jejunum (J), ileum (I), and colon (C), in relation to the control group (Co). Data as mean \pm S.E.M.

Number of experiments: 8 .

Statistically different from control $* \mathrm{p}<0.05$

\section{DISCUSSION}

From the results obtained in the experiments of acute oral toxicity it could be conclude that $P$. sagittalis is a plant that has no significant risk of acute toxicity if swallowed, based on the classification of Van Den Heuvel et al.(13).

Since the extracts of the leaves and stalk reduced the absorption of water in the jejunum, and jejunum and colon, respectively, it is possible that these extracts have substances that can alter the absorptive mechanisms. These substances could be tannins, which are presented in $P$. sagittalis (1). The tannins can precipitate the proteins of the enterocytes, reducing the intestinal secretions, and consequently, produce an anti-diarrhoeic effect (14).

Sodium is absorbed from the lumen to the intracellular medium (apical membrane) due to the action of specific carriers, which transport $\mathrm{Na}^{+}$with others ions $\left(\mathrm{Na}^{+} / \mathrm{Cl}^{-}\right.$and $\mathrm{Na}^{+} / \mathrm{H}^{+}$ cotransport, for example) or organic substances. In the basolateral membrane, the transport of this ion is made by the $\mathrm{Na}^{+} / \mathrm{K}^{+}$pump (15).

The high intracellular concentration of $\mathrm{K}^{+}$is maintained by the $\mathrm{Na}^{+} / \mathrm{K}^{+}$pump of the 
basolateral membrane. Consequently, its secretion from the intracellular medium to the lumen or its absorption by the extracellular medium could occur because its electrochemical potential (16). Another transport system suggested to explain the absorption of $\mathrm{K}^{+}$is the $\mathrm{Na}^{+} / \mathrm{K}^{+} / 2 \mathrm{Cl}^{-}$cotransport, electroneutral, described in the thick ascending limb of Henle's loop of several mammalian species, in erythrocytes, gallbladder, in the amphibian jejunum and the intestine of the fishes (17).

The increase of the absorption of $\mathrm{Na}^{+}$and $\mathrm{K}^{+}$in some portions of the gastrointestinal tract due to the addition of the extracts (mainly stalk) of $P$. sagittalis suggest that these extracts affect the $\mathrm{Na}^{+} / \mathrm{K}^{+} / 2 \mathrm{Cl}^{-}$cotransporter. Alternately, comparing the increase of the absorption of $\mathrm{Na}^{+}$ and $\mathrm{K}^{+}$induced by the extracts, it can be observed that the flow of $\mathrm{Na}^{+}$is greater, indicating the presence of another transport system for this ion. From the results obtained it could be concluded that the extracts from the leaves, stalk, and flowers of $P$. sagittalis have substances that can alter the absorption of ion and water of the gastrointestinal tract. The concentration of these substances could be different in each extract, since the effects were different. The phytochemical studies of $P$. sagittalis cited in the introduction include all aerial portions in the extracts. Consequently, it is not possible to correlate these findings with the hypothesis that the extracts from the leaves, stalk, and flowers of this plant have different active principles (or different amounts of the same principles). Martino et al. detected the presence of caffeoylquinic acids in this plant (18). Czoc and Schulze observed that the injection of caffeic acid in rats increased the secretion of bile (19). The coleretic and colagogue action of $P$. sagittalis described by Udaondo et al. could be related to the presence of these substances (10). Since the crude aqueous extracts from leaves, stalk and flowers of $P$. sagittalis altered the absorption of water, $\mathrm{Na}^{+}$, and $\mathrm{K}^{+}$, it is possible that the ingestion of these extracts could alter the levels of these ions in the plasma. Additional studies must be done to determine these effects.

\section{REFERENCES}

Baldisserotto, B. and Mimura, O. M. (1994). Ion transport across the isolated intestinal mucosa of Anguilla anguilla (Pisces). Comparative Biochestry and Phisiology, 108 $^{\mathbf{A}}(2 / 3): 297-302,1994$.

Baldisserotto, B.; Mimura, O. M. and Salomão, L. C. (1993). Effect of $\mathrm{pH}$ on ion and water transport in the gut of the freshwater teleost, Synbranchus marmoratus. Ciência e Cultura, 45 (6):396-398, 1993.

Chawla, A.S.; Kaith B.S. and Handa S.S. (1991). Chemical investigation and antiinflamatory activity of Pluchea lanceolata. Fitoterapia, LXII(5):441-444, 1991

Costa, A. F. (1994). Farmacognosia. 5 ed. Lisboa: Fundação Calouste Gulbekian, 3v. V. I., 1994.

Czoc, V. G. and Schulze, P. J. (1993). Die Wirkung von Clhrogensäure, Kaffeesäure und Chinasäure nach i.v. Aplikation auf den Gallefluss der Ratte. Zeitschrift für Ernährunswissenschaft, 12 (3):224-236, 1993.

Larini, L. Toxicologia. (1987). 1 ed. São Paulo: Manole, p. 47-57, 1987.

Martino V. S., Debenedetti S. and Coussio J.D. (1979). Caffeoylquinic acids from Pterocaulon virgatum and Pluchea sagittalis. Phytochemistry, 18:2052, 1979.

Martino V.S., Ferraro G.E., Debenedetti S.L. and Coussio J.D. (1984). Compuestos Polifenólicos aislados de Pluchea sagittalis (Compuestas). Acta Farm. Bonaerense, 3(2):141-6, 1984.

Martino V.S., Ferraro G.E., Debenedetti S.L. and Coussio J.D. (1989). Determinación espectrofotométrica del contenido de ácidos cafeoilquínicos en espécies argentinas de compoestas usadas en medicina popular. Acta Farm. Bonaerense, 8(1):3-9, 1989.

Powell, D. W. Ion and water transport in the intestine. (1987). In Andreoli, T. E., Hoffman, J. F., Faunstial, D. O. et al. Transport in organized systems. New York: Plenum medical book company, 1987:175212.

Sanioto, S. M. L. (1991). Absorção Intestinal.In Aires, M. M.. Fisiologia. Rio de Janeiro: Guanabara Koogan, 1991:630-648. 
Sen, T., Ghosh, T.K. and Nag Chaudhuri A.K. (1993). Studies on the mechanism of antiinflamatory and anti-ulcer activity of Pluchea indica - Probable involvement of 5lipooxygenase pathway. Life Sciences, 52:737-743, 1993.

Sen; T. and Nag Chaud Huri A.K. (1991). Antiinflamatory evaluation of a Pluchea indica root extract. J. Ethnopharmacology, 33:135-141, 1991.

Talenti, E.C.J. (1976). Study of the principle chemical components of Pluchea sagittalis (Lam.) Cabrera 6th Communication. Essenze deiv agrum, 46(1):40-57, 1976.

Talenti, E.C.J., Manzi, R., Tedone, F.A., Aringoli E. and Yunes R.A. (1969). Estudo metodológico de la Pluchea sagittalis (Lam) Cabr. Rev. Fac. Ingenieria Química, 38:251267, 1969.

Uchiyama, T., Miyase, T., Ueno, A. And Usmanghani K. (1989). Terpenic glycosides from Pluchea indica. Phytochemistry, 28(12):3369-3372, 1989.

Uchiyama, T., Miyase, T., Ueno, A. and Usmanghani K. (1991) Terpene and lignan glycosides from Pluchea indica. Phytochemistry, 30(2):655-657, 1991.

Udaondo, B., Gonalons, G.P., Basile, A.R., Zunino, H. and Lacour J.J. (1937). Contribuición al estudio de la yerba del lucero (Pluchea suaveolens) (Velloso, de Candolle, O. Kuntze). Bol. Acad. Nac. Med. Buenos Aires, 20:441-460, 1937.

Van Den Heuvel, M. J., Clark, D. G., Fielder, R. J. Koundakjian, P. P., Oliver, G. J. A. , Pelling, D., Tomlinson, N. J. and Walker, A. P. (1990). The international validation of a fixed-dose procedure as an alternative to the classical LD50 test. Ed Chem. Toxicol. 28(7):469-482, 1990.
Received: July 09, 1997; Revised: November 14, 1997; Accepted: November 12, 1998. 